JURNAL PANALUNGTIK

e-ISSN: 2621-928X V Vol. 4 (1), Juli 2021, pp $47-60$

DOI: https://doi.org/10.24164/pnk.v4i1.61

\title{
EVALUASI PADA PENGELOLAAN, PEMANFAATAN, DAN PELESTARIAN \\ CAGAR BUDAYA BERKELANJUTAN PADA SITUS MAJAPAHIT, TROWULAN
}

Evaluation of Sustainable Management, Utilization, and Conservation of Majapahit

Site, Trowulan

\author{
Theodorus Aries Briyan Nugraha Setiawan Kusuma' ${ }^{1}$ ), Andika Witono²), dan \\ Andry Hikari Damai ${ }^{3}$ ) \\ 1) Arkeolog Pendamping Komunitas Wastwantara, Yogyakarta, Indonesia \\ 2) Institut Komunikasi dan Bisnis LSPR \\ Jalan K.H. Mas Mansyur Kav 35, Jakarta, Indonesia \\ 3) Program Studi Arkeologi, Fakultas Ilmu Budaya, Universitas Udayana, \\ Jalan Pulau Nias No. 13, Denpasar, Bali, Indonesia \\ E-mail: theodorusbrian@gmail.com
}

\begin{abstract}
Archaeological remainin at Trowulan site, Mojokerto are one of the important assets in the world of Indonesia archaeology because it holds many valuable lessons from the past. Currently the Trowulan Site has not been able to show a big role for the wider community. This can be seen from the lack of awareness and socialization to the community. The problem raised in this study is how the implementation of management, utilization, and preservation is very necessary in establishing cooperation for the sustainability of archaeological remaining in heritage sites of the Majapahit Kingdom in Trowulan, Mojokerto. This study aims to see the implementation of the management, utilization, and preservation of the Majapahit Trowulan site as an archaeological site that has the potential to be developed. This study uses a descriptive analytic approach by observing the community around the Majapahit site in Trowulan. The data collection technique used a documentation study in the form of a map of the distribution of the Majapahit site in Trowulan and a literature study through previous research. The analysis used in this research is interactive analysis. The purpose of this study is to preserve the heritage sites of the Majapahit Kingdom by protecting the site such as rescue and security, zoning, maintenance and restoration for sustainable for generation to generation. These conservation efforts have been implemented but also still face a lot of obstacles such as human resources.
\end{abstract}

Keywords: conservation, Majapahit site, management, sustainability, utilization

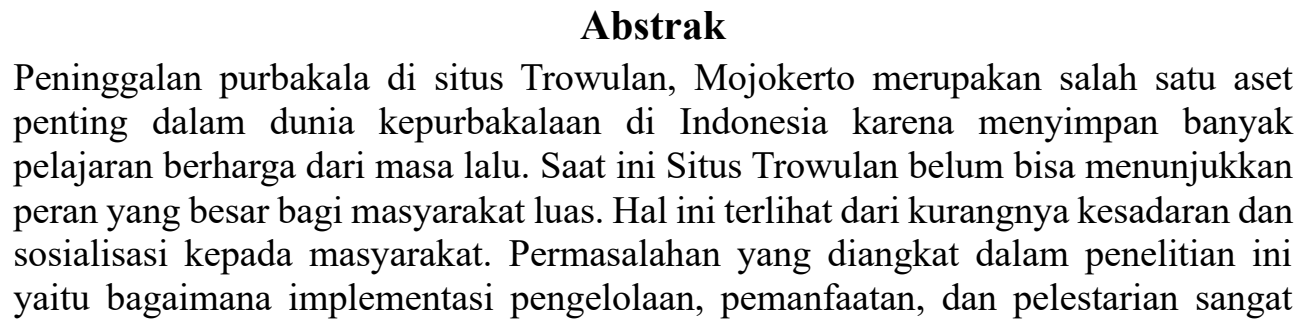




\begin{abstract}
diperlukan dalam menjalin kerjasama demi keberlangsungan tinggalan arkeologis di situs-situs peninggalan Kerajaan Majapahit di Trowulan, Mojokerto. Penelitian ini bertujuan untuk melihat wujud implementasi dari pengelolaan, pemanfaatan, dan pelestarian situs Majapahit Trowulan sebagai situs purbakala yang berpotensi untuk dikembangkan. Penelitian ini menggunakan pendekatan deskriptif analitik dengan observasi masyarakat sekitar situs Majapahit di Trowulan. Teknik pengumpulan data menggunakan studi dokumentasi berupa peta persebaran situs Majapahit di Trowulan dan studi pustaka melalui penelitian sebelumnya. Analisis yang digunakan dalam penelitian ini yaitu analisis interaktif. Tujuan penelitian ini agar pelestarian situs tinggalan Kerajaan Majapahit dilakukan dengan melakukan perlindungan terhadap situs seperti penyelamatan dan pengamanan, zonasi, pemeliharaan, dan pemugaran untuk keberlanjutan dari generasi ke generasi. Upaya-upaya pelestarian tersebut sudah terlaksana namun juga masih menghadapi hambatan seperti sumber daya manusia.
\end{abstract}

Kata kunci: keberlanjutan, pelestarian, pemanfaatan, pengelolaan, situs Majapahit

\title{
PENDAHULUAN
}

Indonesia merupakan negara dengan peninggalan bangunan cagar budaya yang sangat banyak jumlahnya, salah satuya adalah candi. Candi-candi tersebut saat ini dimanfaatkan sebagai daya tarik wisata budaya dan sejarah. Tidak seperti candi yang telah masuk ke dalam warisan dunia seperti Prambanan dan Borobudur, candi yang terletak di area pedesaan meskipun telah diinventarisasi dan dirawat oleh Balai Pelestarian Cagar Budaya banyak yang terbengkalai, tidak terawat, dan berakibat pada hilangnya nilai penting. Upaya masyarakat merawat tinggalan arkeologis cukup tinggi namun ada pula yang membiarkan peninggalan tersebut sehingga rusak dan hilang. Material candi juga digunakan untuk material bangunan rumah atau digunakan untuk lainnya, karena kesengajaan, keterbatasan wawasan atau ketidaktahuan akan nilai penting dari situs tersebut. Namun perlu dicermati bahwa hal-hal tersebut terjadi disebabkan kurangnya sosialisasi pada masyarakat luas.

Salah satu kerajaan masa lampau yang memiliki banyak tinggalan arkeologis adalah kerajaan Majapahit. Banyaknya situs peninggalan Majapahit khususnya di wilayah Trowulan Jawa Timur ini pada dasarnya sangat potensial untuk dapat dikembangkan lebih lanjut terutama yang berkaitan dengan pembangunan karakter masyarakat dan wisatawan. Daerah yang memiliki tinggalan arkeologis berpeluang besar dalam peningkatan kualitas hidup masyarakat sekitar situs tersebut. Peningkatan kualitas ini dapat juga diiringi dengan peningkatan pendapatan masyarakat. Jika ditinjau dari sudut pandang kebudayaan, keberlanjutan dari tinggalan arkeologis pada situs Majapahit dapat membangun kesadaran masyarakat terhadap pentingnya sejarah, budaya, kearifan lokal, khususnya sebagai penanda identitas atau karakter suatu tempat.

Sekilas jika menilik pada masa Kerajaan Majapahit dari tahun 1293 hingga 1500 Masehi dapat dikatakan bahwa yang terjadi selama masa itu adalah sebuah bentuk keberlanjutan yang berlandaskan tidak hanya segi politis kerajaan melainkan peranan masyarakat dalam mempertahankan ciri khas budaya serta keberagaman yang dipegang teguh (Mulyana, 1965). Sesudah mencapai puncaknya pada abad ke-14, Majapahit 
berangsur-angsur melemah dan akhirnya runtuh. Runtuhnya Majapahit ini bukan berarti menghilangkan karisma dan kebesaran Majapahit. Kawasan Cagar Budaya Trowulan memiliki banyak situs di antaranya Candi Brahu, Candi Wringin Lawang, Candi Bajang Ratu, Candi Tikus, Candi Kedaton, Candi Gentong, Makam Putri Cempa, Situs Lantai Segi Enam Sentonorejo, Makam Panjang, Siti Inggil, Candi Minak Jinggo, Situs Umpak Sentonorejo. Selain situs percandian tersebut juga ditemukan Kolam Segaran yang diduga kuat sebagai pusat irigasi untuk mengairi lahan pertanian Kerajaan Majapahit. Dengan ditemukannya berbagai situs candi tersebut seakan menguak kembali tabir sejarah dari Kerajaan Majapahit (Soeroso, 1983).

Berdasarkan banyaknya pertimbangan tentang keberlangsungan situs-situs tinggalan Majapahit, begitu juga dengan adanya potensi besar untuk terus melestarikannya sebagai sebuah penanda identitas kebangsaan, maka pada artikel ini akan membahas lebih lanjut tentang keberlanjutan yang seharusnya perlu dicermati dalam pengembangan, pemanfaatan, dan pengelolaan situs tinggalan Majapahit. Salah satu pemanfaatan situs-situs di Trowulan adalah sebagai tujuan wisata karena potensinya yang sangat besar. Potensi wisata menurut Yoeti (1983) adalah segala sesuatu yang terdapat di daerah tujuan wisata, dan merupakan daya tarik agar orang-orang mau datang dan berkunjung ke tempat tersebut. Sukardi (1998) mengungkapkan pengertian yang sama tentang potensi wisata, sebagai segala yang dimiliki oleh suatu daya tarik wisata dan berguna untuk mengembangkan industri pariwisata di daerah tersebut.

Permasalahan yang diangkat dalam penelitian ini yaitu bagaimana implementasi pengelolaan, pemanfaatan dan pelestarian sangat diperlukan dalam menjalin kerjasama demi keberlangsungan tinggalan arkeologis di situs-situs peninggalan Kerajaan Majapahit di Trowulan, Mojokerto. Situs peninggalan Kerajaan Majapahit memiliki nilainilai penting yang berguna untuk masyarakat sekitar, akademisi, hingga pemerintah. Penelitian ini bertujuan untuk melihat wujud implementasi pengelolaan, pemanfaatan dan pelestarian situs Majapahit Trowulan sebagai kawasan situs arkeologi yang memiliki potensi untuk dikembangkan.

Salah satu acuan pengembangan kawasan atau situs tinggalan arkeologis tertuang dalam Undang-Undang Republik Indonesia Nomor 11 Tahun 2010 tentang Cagar Budaya yang menjelaskan bahwa cagar budaya adalah suatu warisan budaya yang bersifat kebendaan berupa Benda Cagar Budaya, Bangunan Cagar Budaya, Struktur Cagar Budaya, Situs Cagar Budaya dan Kawasan Cagar Budaya baik di darat dan/atau di air yang perlu dilestarikan keberadaannya karena memiliki nilai penting bagi sejarah, ilmu pengetahuan, pendidikan, agama dan/atau kebudayaan melalui proses penetapan. Oleh karena itu berdasarkan pada peraturan yang ada, maka perlu adanya suatu upaya dalam melindungi, mengembangkan dan memanfaatkan cagar budaya melalui berbagai kebijakan dalam kaitannya dengan perencanaan, pelaksanaan dan pengawasan yang diperuntukkan bagi masyarakat luas.

Bentuk nyata yang dapat digunakan dalam implementasi acuan pengembangan kawasan atau situs arkeologis menurut Undang-Undang Republik Indonesia Nomor 11 Tahun 2010 dalam rangka pengembangan kawasan berbasis kemasyarakatan. 
Berdasarkan pada upaya tersebut, maka dalam penelitian ini digunakan beberapa hasil penelitian terdahulu berupa data peta sebaran tinggalan arkeologis dan data potensi daya tarik wisata arkeologis.

Suatu upaya pelestarian cagar budaya merupakan suatu bentuk dinamis yang bertujuan untuk mempertahankan keberadaan cagar budaya beserta nilainya dengan cara melindungi, mengembangkan dan memanfaatkan. Pada hakekatnya pengelolaan cagar budaya tidak hanya berdasarkan pada sebuah keuntungan semata, tetapi juga perlu mengedepankan edukasi yang bersifat berkelanjutan, agar dapat membentuk suatu rangkaian masyarakat yang secara sadar ikut menjaga dan melestarikan tinggalan budaya yang ada di sekitarnya.

Penelitian ini menggunakan metode deskriptif analitik dengan pendekatan kualitatif, yaitu melakukan pengamatan pada data yang sudah dikumpulkan dan mendeskripsikan objek yang diteliti serta membuat kesimpulan yang berlaku untuk umum (Mulyana 2010). Fokus utama dalam penelitian ini yaitu, pengelolaan, pemanfaatan, dan pelestarian pada situs peninggalan Kerajaan Majapahit, serta peran serta pemangku kepentingan dalam proses perjalanan pengembangan. Teknik pengumpulan data yang digunakan yaitu melalui observasi, pengumpulan sumber primer melalui pengumpulan arsip dokumentasi berupa peta persebaran situs yang ada di Trowulan, serta pengumpulan sumber sekunder melalui pustaka mengenai penelitian pengelolaan, pemanfaatan, dan pelestarian situs cagar budaya yang ada di Trowulan. Studi dokumentasi yang digunakan adalah dengan melihat pada hasil penelitian terdahulu dalam berbagai aspek seperti pengelolaan, pemanfaatan, pemetaan wilayah dan juga analisis keruangan di situs tinggalan arkeologi Majapahit.

Berdasarkan data studi dokumentasi diharapkan dapat menjawab permasalahan yang ada dan menjadi bahan pertimbangan untuk keberlangsungan situs Majapahit ke depannya. Tinjauan pustaka berupa peta terdahulu terkait sebaran situs dan korelasinya berdasarkan pada penentuan luasan dan data arkeologi. Data hasil dari penelitian ini akan dianalisis menggunakan teknik analisis interaktif yang terdiri atas pengumpulan data, penyajian data dan penarikan kesimpulan. Data penelitian terdahulu akan menjadi acuan untuk melihat ada dan tidaknya perubahan pola sebaran situs tinggalan arkeologi di Trowulan.

Penelitian ini akan menggunakan beberapa acuan pustaka yang memberikan dampak signifikan bagi implementasi pengelolaan, pemanfaatan dan pelestarian cagar budaya di situs Majapahit. Pustaka ini digunakan sebagai ide utama dalam penentuan arah penulisan artikel ini. Bentuk konsep pelestarian arkeologis menurut pandangan Daud Aris Tanudirjo adalah bentuk upaya aktualisasi warisan budaya dan cagar budaya yang disesuaikan dengan kondisi terkini dan memberikan makna baru. Pada hal ini ditekankan pula bahwa perbedaan pemberian makna pada warisan budaya haruslah diwadahi dan dihargai sebagai keputusan yang demokratis (Tanudirjo, 1998). Artikel ini membantu dalam memberikan penjelasan mengenai besarnya peranan masyarakat terhadap keberlanjutan cagar budaya terutama untuk situs Majapahit di Trowulan, Mojokerto.

W. Djuwita Sudjana Ramelan, Supratikno Rahardjo, Karina Arifin, Myrna 
Laksman Hunltley, Ingrid, H. E. Pojoh, Agi Ginanjar menuliskan bahwa ada cara-cara komunikasi yang lebih baik dan demokratis dalam penanganan sumber daya arkeologi agar tidak lagi ada jarak antara pemangku kepentingan dan masyarakat dalam bidang arkeologi (Ramelan et al., 2015). Artikel ini membantu dalam rancangan strategis untuk keberlanjutan situs di Trowulan beserta regulasi yang menaungi untuk pemanfaatan dan pelestarian situs Majapahit di Trowulan.

Sementara itu Habib Subagio dan Aris Poniman menjelaskan bahwa ada potensi besar tinggalan arkeologi di Trowulan yang berkaitan dengan tinggalan kerajaan Majapahit. Data pemetaan yang dihasilkan setidaknya mampu menjadi acuan dalam penentuan arah kebijakan bagi situs Trowulan (Subagio \& Poniman, 2010). Artikel ini membantu dalam rancangan zonasi berdasarkan pemantauan aktivitas setempat sebagai upaya konservasi, perlindungan, dan keberlanjutan situs di Trowulan.

Eka Sapta Kartika Putri, Antariksa, Wisnu Sasongko menyajikan data terkait sebaran tinggalan arkeologi yang ada di Desa Trowulan dan Desa Sentonorejo di Kecamatan Trowulan memiliki potensi budaya yang cukup tinggi jika mampu diarahkan. Data yang disajikan berupa peta lokasi situs, dan juga statistik budaya (Putri et al. 2017). Artikel ini membantu dalam memberikan gambaran berupa penjabaran dan pendetilan strategi pelestarian untuk meningkatkan citra kawasan cagar budaya Trowulan terhadap lima atribut place sebagai upaya meningkatkan partisipasi dan kesadaran masyarakat.

\section{HASIL DAN PEMBAHASAN}

Situs tinggalan Kerajaan Majapahit yang paling terkenal adalah situs Trowulan yang diduga merupakan situs pemerintahan pusat Majapahit. Beragam temuan yang bersifat monumental ditemukan di sana seperti candi, petirtaan, pintu gerbang, fondasi bangunan sampai pada temuan artefak berupa arca, relief peralatan upacara dan peralatan rumah tangga. Situs Trowulan merupakan kawasan paling banyak menyimpan tinggalan Majapahit. Terbagi dalam dua wilayah desa yakni Desa Trowulan sebanyak delapan situs dan Desa Sentonorejo sebanyak empat situs dari total 17 situs yang ada di kecamatan Trowulan (Gambar 1). 


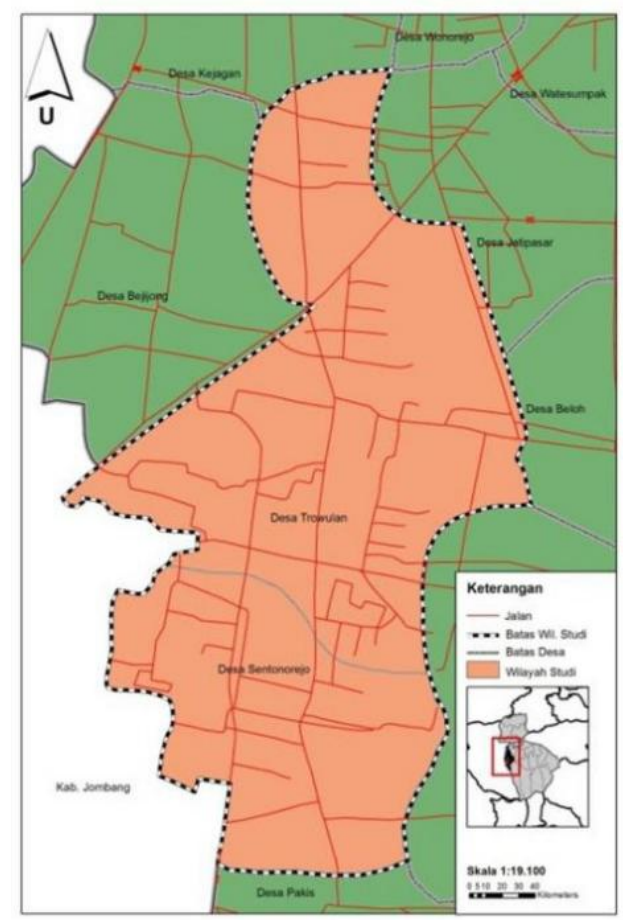

Gambar 1. Peta lokasi Desa Trowulan dan Desa Sentonorejo, Kec. Trowulan (Sumber: Putri et al.

2017).

\section{Tapal Batas Kota Majapahit}

Penentuan batas kota Majapahit masih menjadi pertanyaan tersendiri dan perdebatan di kalangan para ahli arkeologi maupun ahli keilmuan lainnya. Hal ini dikarenakan belum adanya tapal batas wilayah yang jelas baik melalui tinggalan arkeologis berupa prasasti, candi maupun arca. Namun konsentrasi temuan terbanyak memang berada di wilayah Trowulan (gambar 2). Hal ini juga berpengaruh pada pembagian wilayah dalam skala mikro maupun makro. Secara mikro dapat dikatakan bahwa Trowulan adalah ibukota kerajaan Majapahit. Namun jika kita melihat pada skala makro, maka tanpa batasan yang riil tidak dapat kita katakan Trowulan adalah ibukota kerajaan Majapahit. Tentunya hal ini perlu diperkuat dan diperjelas kembali dengan adanya tinggalan arkeologis yang memang dapat dipertanggungjawabkan. 


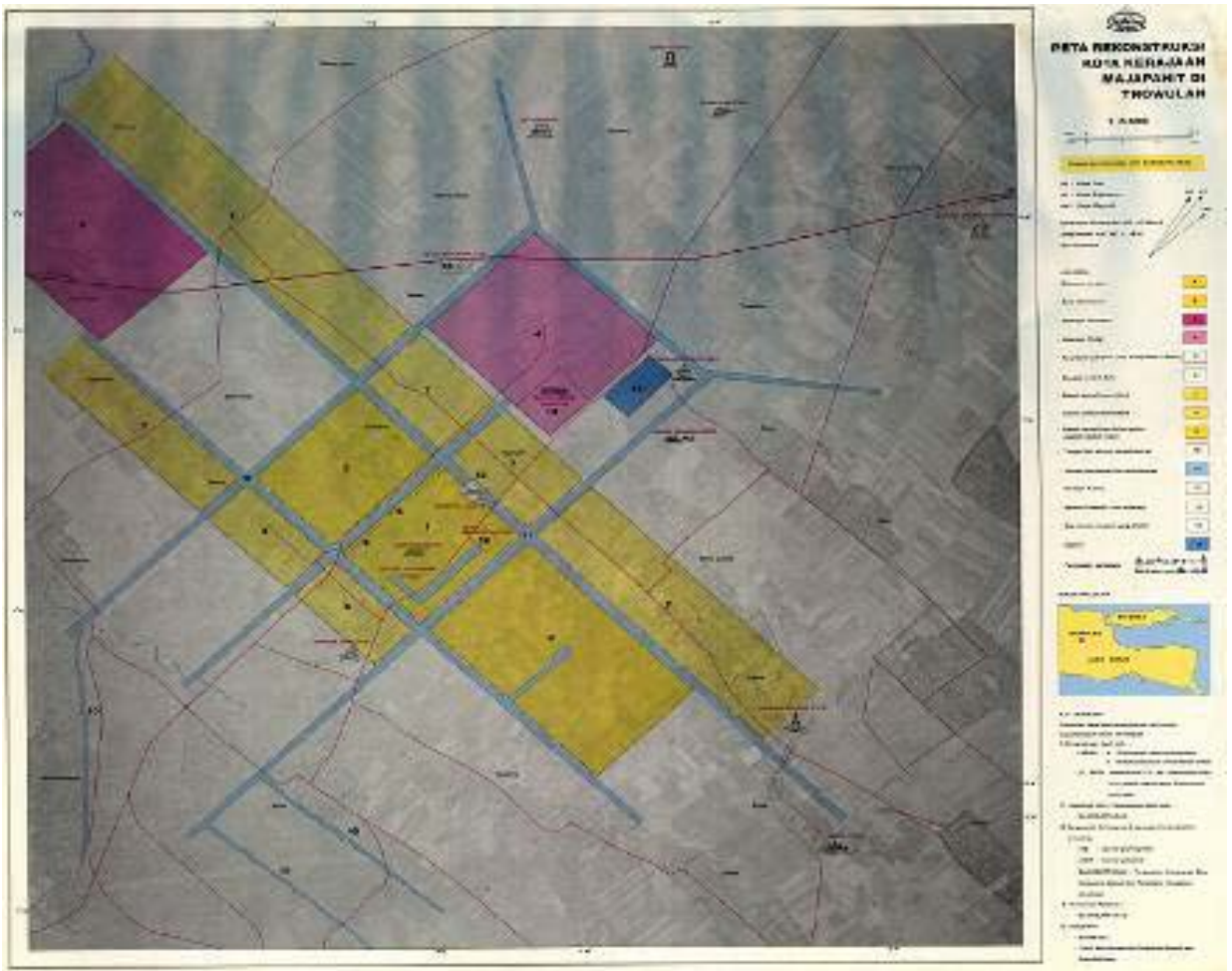

Gambar 2. Scan Peta Tinggalan Kerajaan Majapahit di Trowulan (Sumber: Subagio dan Poniman 2010).

Sementara itu, penentuan batas wilayah kota Majapahit yang diketahui didasarkan pada sebaran empat yoni yang menjadi penandanya (Subagio \& Poniman, 2010). Dengan luasan 9 X $11 \mathrm{~km}$ maka didapatkan permodelan dengan skenario A dan B (gambar 3) yang masing-masing merepresentasikan pembagian wilayah berdasarkan pada data arkeologis. Pada wilayah dengan kode A didasarkan pada sebaran empat yoni sebagai penanda batas wilayah kota Majapahit. Sedangkan pada kode B menggunakan batasan bentang alam berupa aliran sungai Kali Konto di bagian utara, Kali Gunting di bagian barat, Kali Brangkal di bagian timur, dan sisi selatan berupa aliran anak sungai yang berasal dari Kali Brangkal dan Kali Gunting. Secara lanskap dapat dikatakan jika batasan dengan kode B merupakan batasan bentang alam di kaki Gunung Penanggungan yang membentang sampai pada daerah dataran rendahnya. 


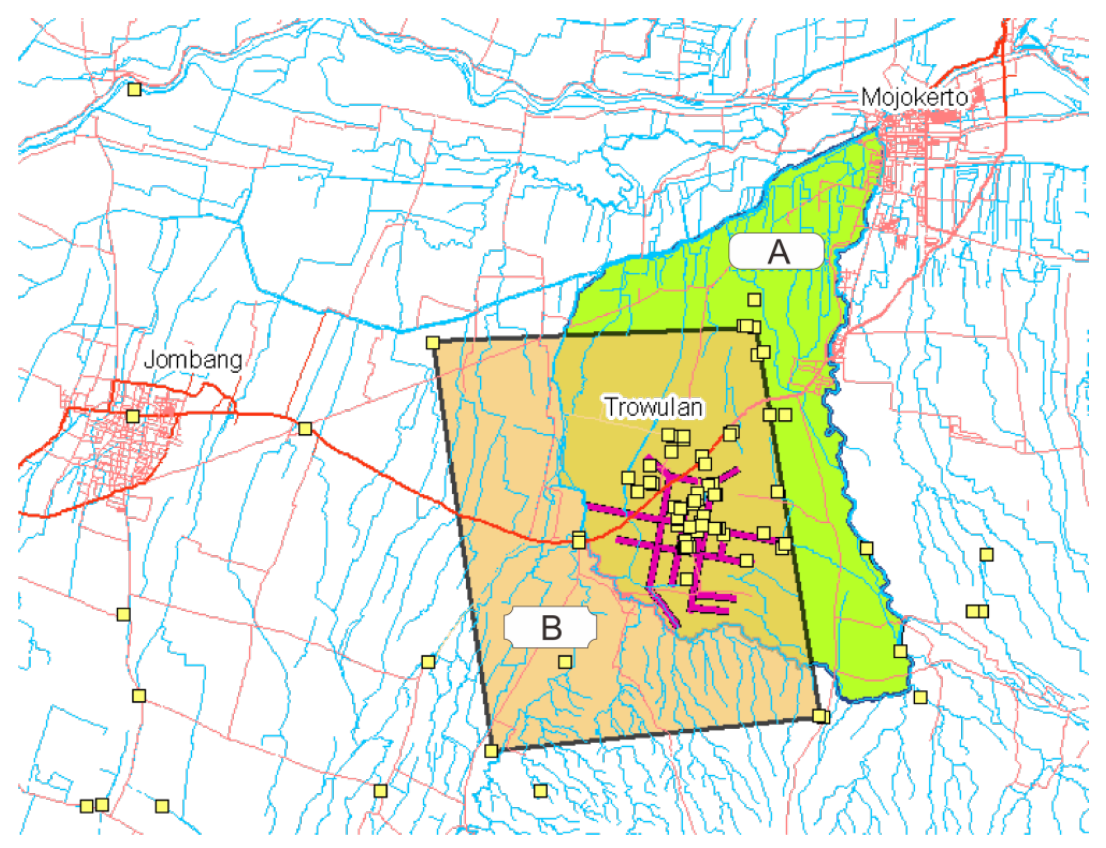

Gambar 3. Rekonstruksi wilayah batas kota Trowulan (Sumber: Subagio dan Poniman 2010).

\section{Sebaran Tinggalan Arkeologi Kerajaan Majapahit}

Kawasan Cagar Budaya Trowulan memiliki tinggalan berupa Kolam Segaran, Candi Menak Jinggo, makam Putri Campa, Kubur Panjang, Kubur Panggung, Pemukiman Nglinguk, Pusat Informasi Majapahit, dan Pendopo Agung. Sedangkan Desa Sentonorejo memiliki tinggalan berupa, situs Kedaton (sumur kuno, sumur upas, dan batu umpak), serta Makam Troloyo (gambar 4). Berdasarkan pada jumlah tinggalan tersebut maka potensi yang bisa dimanfaatkan sungguh besar baik dalam segi wisata maupun pengembangan keberlanjutannya. 


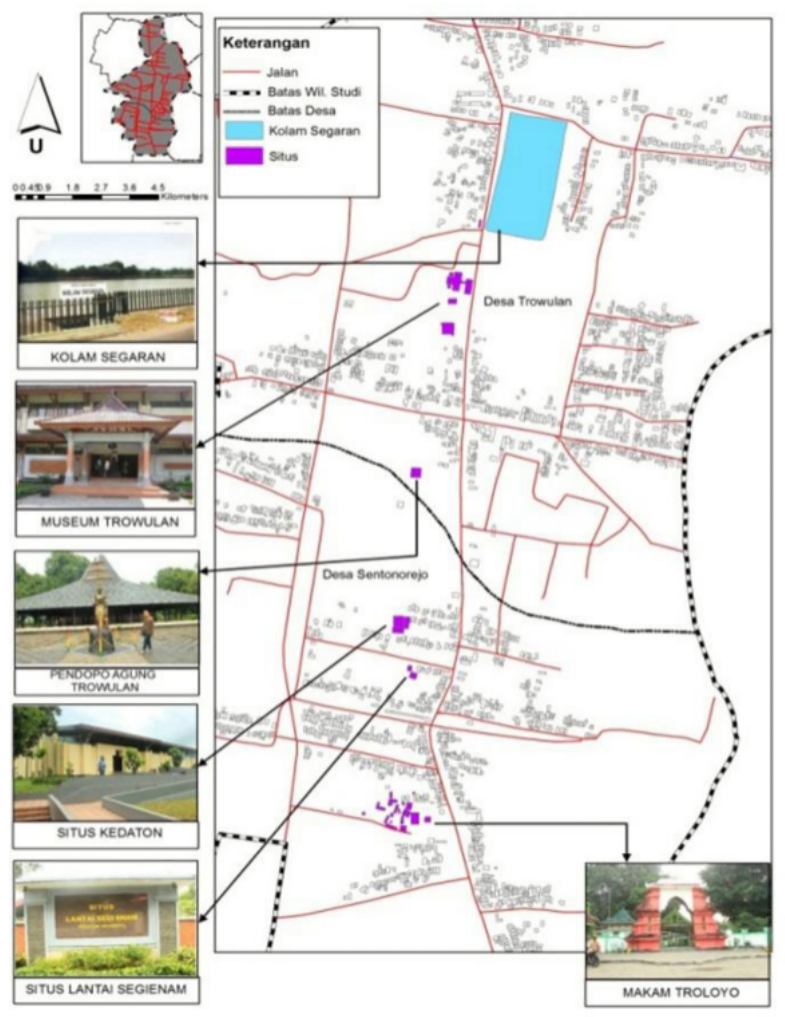

Gambar 4. Peta sebaran situs Trowulan (Sumber: Putri et al. 2017).

\section{Tantangan dalam Pengelolaan, Pemanfaatan, dan Pelestarian Situs Tinggalan}

\section{Arkeologi Majapahit}

Namun pada kenyataannya, pengembangan situs tinggalan Kerajaan Majapahit memiliki banyak hal yang perlu diperhatikan. Salah satu hal yang perlu menjadi perhatian khusus adalah adanya kegiatan pembuatan bata merah dengan bahan baku utama tanah liat sawah yang secara tidak langsung menjadi ancaman bagi tinggalan arkeologis di situs Majapahit. Hal ini memicu keprihatinan yang cukup serius dikarenakan tingginya permintaan terhadap bahan baku bata merah. Sisi negatif yang timbul dari kegiatan pencarian bahan baku bata merah adalah rusaknya lingkungan situs dan hancurnya beberapa struktur bangunan kuna, padahal tinggalan Majapahit merupakan daya tarik wisata yang menjadi ciri khas tersendiri dan masih berkaitan erat dengan nilai kesejarahan yang dimiliki oleh Kerajaan Majapahit. Daya tarik tinggalan Majapahit yang tersebar itu akan dibagi menjadi tiga jenis daya tarik yaitu:

1. Daya Tarik Budaya yang meliputi tinggalan sejarah, budaya, dan arkeologis Kerajaan Majapahit yang tersimpan di situs-situs peninggalan Kerajaan Majapahit di Trowulan seperti candi, gapura, dan PIM (Pusat Informasi Majapahit), serta kesenian lokal pedesaan seperti jatilan, wayangan, dan pola hidup keseharian masyarakat pedesaan. 
2. Daya Tarik Wisata Alam yang dapat diasosiasikan dengan kondisi bentang alam pedesaan disekitaran wilayah Trowulan khususnya dan Jawa Timur pada umumnya.

3. Daya Tarik Minat Khusus seperti pengenalan akan kegiatan ekskavasi, pembelajaran Bahasa Jawa Kuna, dan juga kegiatan kesenian yang bercorak Majapahit.

Dalam tiga jenis tersebut perlu disoroti pada bagian ketiga yaitu adanya pengenalan kegiatan ekskavasi dan juga pembelajaran pada masyarakat luas. Hal ini dimaksudkan agar tercapainya masyarakat yang peduli akan tinggalan arkeologis Majapahit dan juga menjadi suatu daya tarik khas yang berpotensi mendatangkan manfaat baik secara budaya dan ekonomi. Namun perlu dicermati juga bahwa pada prosesnya tidak bisa berjalan dengan mudah karena perlu mengedepankan keamanan dari keberadaan situs tinggalan Majapahit itu sendiri. Tinggalan arkeologis Majapahit sendiri bersifat rapuh, tidak bisa diperbaharui dan tidak tergantikan dengan apapun. Pengembangan dan juga pemanfaatan haruslah disertai dengan adanya pengelolaan dan pelestarian yang berkesinambungan.

Pengelolaan tinggalan Majapahit berlandaskan pada Peraturan Daerah Provinsi Jawa Timur Nomor 6 Tahun 2017 Tentang Rencana Induk Pembangunan Kepariwisataan Provinsi Jawa Timur Tahun 2017-2032, Undang-Undang Republik Indonesia Nomor 10 Tahun 2009 tentang Kepariwisataan, Undang-Undang Republik Indonesia Nomor 11 Tahun 2010 tentang Cagar Budaya, Peraturan Menteri Pendidikan dan Kebudayaan Nomor 52 Tahun 2012 tentang Organisasi dan Tata Kerja Balai Pelestarian Cagar Budaya, Peraturan Menteri Pendidikan dan Kebudayaan Nomor 28 Tahun 2013 tentang Rincian Tugas Balai Pelestarian Cagar Budaya, Keputusan Menteri Pendidikan dan Kebudayaan Nomor 260 Tahun 2013 tentang Penetapan Satuan Ruang Geografis Trowulan Sebagai Kawasan Cagar Budaya Nasional, dan Peraturan Daerah Kabupaten Mojokerto Nomor 9 Tahun 2012 tentang Rencana Tata Ruang Wilayah Kabupaten Mojokerto Tahun 20122032. Secara keseluruhan berdasarkan pada peraturan-peraturan tersebut belum ada yang secara khusus membahas tentang pengelolaan dan pelestarian tinggalan arkeologis Majapahit. Oleh karena itu, diperlukan suatu bentuk regulasi khusus yang mengatur tentang tata kelola tinggalan Majapahit agar tidak terjadi tumpang-tindih dalam regulasinya.

Dalam kaitannya dengan kegiatan penyelamatan dan pengamanan tinggalan arkeologis Majapahit diperlukan adanya sosialisasi secara berkala yang dapat dilakukan oleh BPCB Jawa Timur yang bekerjasama dengan berbagai komunitas budaya atau masyarakat pada umumnya. Hal ini dilakukan sebagai upaya pencegahan terhadap kerusakan atau kehilangan pada temuan tinggalan arkeologis yang ada. Keberadaan sebaran tinggalan arkeologis Kerajaan Majapahit juga memerlukan adanya sistem zonasi yang lebih akurat dan jelas. Penetapan batas-batas zonasi dan pemanfaatan keruangannya harus berdasarkan pada peraturan daerah yang ada. Selama ini belum adanya penentuan batas berdasarkan zonasi menyebabkan kurangnya pengawasan terhadap tinggalan 
arkeologis Majapahit. Pelibatan ahli arkeologi dan juga keilmuan lain dapat membantu mempercepat tercapainya pembuatan zonasi agar dapat disinergiskan dengan kondisi pembangunan yang dilakukan oleh pemerintah pusat maupun daerah.

Keberlanjutan situs tinggalan arkeologis Majapahit dapat tercapai apabila adanya upaya pemeliharaan dan pemugaran. Pemeliharaan bertujuan agar kondisi situs selalu terjaga dan terpantau dengan baik, sedangkan pemugaran dilakukan agar kondisi situs yang rusak dapat segera diperbaiki dengan mengedepankan urgensitas yang ada. Pihak yang memiliki wewenang penuh dalam hal ini adalah BPCB Jawa Timur. Sedangkan sarana dan prasarana pendukung dapat dilakukan oleh pemerintah daerah. Keberadaan juru pelihara juga menjadi kunci keberhasilan dalam pemeliharaan situs. Dalam hal ini peranan juru pelihara menjadi salah satu faktor penting sebagai sosok yang berperan sebagai pemelihara situs sekaligus penyampai informasi kepada pengunjung situs. Namun kondisi yang terjadi masih jauh dari apa yang diharapkan. Diperlukan evaluasi menyeluruh agar peranan juru pelihara menjadi lebih maksimal.

Selain mencermati hal-hal di atas, juga diperlukan adanya kerjasama dengan berbagai pihak dalam proses perjalanannya. Salah satu faktor yang tidak kalah penting yaitu, melakukan konservasi pada situs tinggalan Majapahit yang memerlukan perhatian dan tindak lanjut. Hal ini dapat dilakukan dengan menjalin kerjasama dari berbagai lintas keilmuan dengan memanfaatkan sumber daya manusia yang ada. BPCB Jawa Timur dapat membuka sistem kerjasama atau jika memungkinkan bisa memberikan tempat bagi mahasiswa arkeologi untuk menjadi tenaga sukarelawan ataupun magang.

Kegiatan pemugaran sangat jarang dilakukan mengingat jangka waktu pengerjaan yang memakan waktu sampai kurang lebih 8 bulan lamanya dalam satu kali kegiatan pemugaran. Hal ini juga tidak didukung dengan penganggaran yang cukup sehingga menjadikan kegiatan pemugaran selalu berlarut-larut. Kemudian, peranan pemangku kepentingan yang terlibat dalam lingkup ini meliputi Bappeda Kabupaten Mojokerto, Disporabudpar Kabupaten Mojokerto, dan BPCB Jawa Timur. Bappeda sebagai pihak perencana. Disporabudpar merupakan SKPD yang menangani urusan kebudayaan sebagai urusan wajib pemerintahan daerah. BPCB sebagai UPT Pemerintah Pusat di lingkungan Kemendikbud, Direktorat Jenderal Kebudayaan.Sementara itu peranan masyarakat sebagai bagian dari pemangku kepentingan dapat dilihat dari peran serta dalam memelihara, menjaga dan mengawasi bagaimana tinggalan arkeologis itu dapat bermanfaat bagi mereka.

Peranan pemangku kepentingan sebagai pemilik kepentingan sekaligus menjadi lembaga yang memiliki peranan utama dalam segala bentuk kegiatan yang terjadi di seluruh situs tinggalan Majapahit. Peranan dari ketiga pemangku kepentingan ini akan menentukan arah kebijakan dalam proses pengembangan sekaligus keberlanjutan dari situs tinggalan Majapahit yang tersebar di berbagai wilayah di Jawa Timur khususnya Trowulan, Mojokerto. 


\section{SIMPULAN}

Pengelolaan Situs Majapahit Trowulan sudah dilaksanakan melalui regulasi yang ada. Selain itu tidak adanya regulasi khusus yang mengatur pengelolaan dan pelestarian situs tinggalan arkeologis dari Kerajaan Majapahit berakibat pada kurangnya kesadaran dan rasa memiliki dari berbagai pihak dalam upaya pelestarian situs tinggalan Kerajaan Majapahit dengan melakukan perlindungan terhadap situs tersebut yang terdiri dari penyelamatan dan pengamanan, zonasi, serta pemeliharaan dan pemugaran. Sejauh ini, upaya-upaya pelestarian tersebut sudah terlaksana, namun juga masih menghadapi hambatan. Hambatan tersebut berupa kurangnya sumber daya manusia yang memadai serta keterbatasan anggaran di tiap tahunnya.

Dalam kegiatan penyelamatan dan pengamanan tinggalan arkeologis Majapahit diperlukan adanya sosialisasi secara berkala yang dapat dilakukan oleh BPCB Jawa Timur yang bekerjasama dengan komunitas budaya atau masyarakat sebagai upaya pencegahan terhadap kerusakan atau kehilangan tinggalan arkeologis. Keberadaan sebaran tinggalan arkeologis Kerajaan Majapahit juga memerlukan penetapan batas-batas zonasi yang lebih akurat dan jelas berdasarkan pada peraturan daerah yang ada dengan melibatkan ahli arkeologi dan keilmuan lain. Selama ini belum adanya penentuan batas berdasarkan zonasi menyebabkan kurangnya pengawasan terhadap tinggalan arkeologis Majapahit.

Adapun upaya keberlanjutan situs tinggalan arkeologis Majapahit berupa pemeliharaan agar kondisi situs selalu terjaga dan terpantau dengan baik, serta upaya pemugaran agar kondisi situs yang rusak dapat segera diperbaiki dengan mengedepankan urgensitas yang ada. Meskipun BPCB Jawa Timur sebagai pemegang wewenang penuh, keberadaan juru pelihara menjadi salah satu faktor penting sebagai sosok yang berperan sebagai pemelihara situs sekaligus penyampai informasi kepada pengunjung situs. Namun kondisi yang terjadi masih jauh dari apa yang diharapkan. Diperlukan evaluasi menyeluruh agar peranan juru pelihara menjadi lebih maksimal. Salah satu faktor yang tidak kalah penting yaitu, melakukan konservasi pada situs tinggalan Majapahit yang memerlukan perhatian dan tindak lanjut. Hal ini dapat dilakukan dengan menjalin kerjasama dari berbagai lintas keilmuan dengan memanfaatkan sumber daya manusia yang ada.

Pemangku kepentingan yang terlibat dalam pengelolaan dan pelestarian situs tinggalan Majapahit tidak hanya masyarakat saja sebagai pihak yang dekat dengan situs atau tinggalan arkeologis di Trowulan melainkan juga Bappeda sebagai pihak perencana, Disporabudpar merupakan SKPD yang menangani urusan kebudayaan sebagai urusan wajib pemerintahan daerah, dan BPCB sebagai UPT Pemerintah Pusat di lingkungan Kemendikbud, Direktorat Jenderal Kebudayaan. Pemerintah baik pusat maupun daerah hendaknya mengumpulkan berbagai lapisan masyarakat mulai dari tokoh masyarakat, pemuka agama, kaum intelektual, serta pihak swasta untuk bersama-sama memikirkan langkah ke depan demi menjaga kelestarian tinggalan Majapahit sebagai suatu kekayaan intelektual yang memiliki nilai penting bagi keberlanjutan masyarakat dan bangsa 
Indonesia khususnya.

\section{DAFTAR PUSTAKA}

Keputusan Menteri Pendidikan dan Kebudayaan Nomor 260 Tahun 2013 tentang Penetapan Satuan Ruang Geografis Trowulan Sebagai Kawasan Cagar Budaya Nasional, (2013).

Mulyana, D. (2010). Metodologi Penelitian Kualitatif: Paradigma Baru Ilmu Komunikasi dan Ilmu Sosial Lainnya. PT Remaja Rosdakaya Offset.

Mulyana, S. (1965). Menuju Puncak Kemegahan: Sejarah Kerajaan Majapahit. Balai Pustaka.

Peraturan Daerah Provinsi Jawa Timur Nomor 6 Tahun 2017 Tentang Rencana Induk Pembangunan Kepariwisataan Provinsi Jawa Timur Tahun 2017- 2032. Diambil 16 September 2021, dari http://arsipjdih.jatimprov.go.id/upload/4337/Perda_No._6_Thn_2017_ttg_Renca na_Induk_Kepariwisataan.pdf

Peraturan Daerah Kabupaten Mojokerto Nomor 9 Tahun 2012 tentang Rencana Tata Ruang Wilayah Kabupaten Mojokerto Tahun 2012-2032, (2012).

Peraturan Menteri Pendidikan dan Kebudayaan Nomor 28 Tahun 2013 tentang Rincian Tugas Balai Pelestarian Cagar Budaya, (2013).

Peraturan Menteri Pendidikan dan Kebudayaan Nomor 52 Tahun 2012 tentang Organisasi dan Tata Kerja Balai Pelestarian Cagar Budaya, (2012).

Putri, E. S. K., Antariksa, \& Sasongko, W. (2017). Citra Kawasan Cagar Budaya Trowulan dan Desa Sentonorejo, Kabupaten Mojokerto. Arsitektur E-Journal, 10(2), 1-11.

Ramelan, W. D. S., Rahardjo, S., Arifin, K., Hunltley, M. L., Pojoh, Ingrid, H. E., \& Ginanjar, A. (2015). Model Pemanfaatan Kawasan Cagar Budya Trowulan Berbasis Masyarakat. Amerta, 33(1), 63-76. https://doi.org/10.24832/amt.v33i1.213

Soeroso, M. P. (1983). Tinjauan Sebab-Sebab Keruntuhan Kerajaan Majapahit. Pusat Penelitian Arkeologi Nasional.

Subagio, H., \& Poniman, A. (2010). Pemanfaatan GIS untuk Rekontruksi Kawasan Strategis Nasional Trowulan. Globë, 12(2), 101-113.

Sukardi, N. (1998). Pengantar Pariwisata. STP Nusa Dua Bali.

Tanudirjo, D. A. (1996). Arkeologi Pasca Modernisme untuk Direnungkan. Pertemuan Ilmiah Arkeologi VII.

Tanudirjo, D. A. (1998). Cultural Resource Management sebagai Manajemen Konflik. Buletin Artefak, 19, 14-18.

Undang-Undang Republik Indonesia Nomor 10 Tahun 2009 tentang Kepariwisataan. Diambil $\quad 14 \quad$ September 2021, dari 
JURNAL PANALUNGTIK — Vol. 4, No. 1, Juli $2021: 47$ - 60

https://www.kemenparekraf.go.id/asset_admin/assets/uploads/media/old_file/46 36_1364-UUTentangKepariwisataannet1.pdf

Undang-Undang Republik Indonesia Nomor 11 Tahun 2010 tentang Cagar Budaya, (2010).

Yoeti, O. A. (1983). Pengantar Ilmu Pariwisata. Angkasa. 